Article

\title{
Studies of Halogen Bonding Induced by Pentafluorosulfanyl Aryl Iodides: A Potential Group of Halogen Bond Donors in a Rational Drug Design
}

\author{
Yuji Sumii ${ }^{1}{ }^{(D)}$, Kenta Sasaki ${ }^{1}$, Seiji Tsuzuki ${ }^{2}$ and Norio Shibata ${ }^{1,3, *(\mathbb{C}}$ \\ 1 Department of Nanopharmaceutical Sciences, and Department of Life Science and Applied Chemistry, \\ Nagoya Institute of Technology, Gokiso, Showa-ku, Nagoya 466-8555, Japan; sumii.yuji@nitech.ac.jp (Y.S.); \\ k.sasaki.699@stn.nitech.ac.jp (K.S.) \\ 2 Research Center for Computational Design of Advanced Functional Materials, AIST, Tsukuba, \\ Ibaraki 305-8568, Japan; s.tsuzuki@aist.go.jp \\ 3 Institute of Advanced Fluorine-Containing Materials, Zhejiang Normal University, 688 Yingbin Avenue, \\ Jinhua 321004, China \\ * Correspondence: nozshiba@nitech.ac.jp; Tel./Fax: +81-52-735-7543
}

Academic Editor: Derek J. McPhee

Received: 24 August 2019; Accepted: 3 October 2019; Published: 7 October 2019

\begin{abstract}
The activation of halogen bonding by the substitution of the pentafluoro- $\lambda^{6}$-sulfanyl $\left(\mathrm{SF}_{5}\right)$ group was studied using a series of $\mathrm{SF}_{5}$-substituted iodobenzenes. The simulated electrostatic potential values of $\mathrm{SF}_{5}$-substituted iodobenzenes, the ab initio molecular orbital calculations of intermolecular interactions of $\mathrm{SF}_{5}$-substituted iodobenzenes with pyridine, and the ${ }^{13} \mathrm{C}-\mathrm{NMR}$ titration experiments of $\mathrm{SF}_{5}$-substituted iodobenzenes in the presence of pyridine or tetra (n-butyl) ammonium chloride (TBAC) indicated the obvious activation of halogen bonding, although this was highly dependent on the position of $\mathrm{SF}_{5}$-substitution on the benzene ring. It was found that $3,5-$ bis-SF $_{5}$-iodobenzene was the most effective halogen bond donor, followed by $0-\mathrm{SF}_{5}$-substituted iodobenzene, while the $m$ - and $p-\mathrm{SF}_{5}$ substitutions did not activate the halogen bonding of iodobenzenes. The similar ortho-effect was also confirmed by studies using a series of nitro $\left(\mathrm{NO}_{2}\right)$-substituted iodobenzenes. These observations are in good agreement with the corresponding Mulliken charge of iodine. The 2:1 halogen bonding complex of 3,5-bis-SF 5 -iodobenzene and 1,4-diazabicyclo[2.2.2] octane (DABCO) was also confirmed. Since $\mathrm{SF}_{5}$-containing compounds have emerged as promising novel pharmaceutical and agrochemical candidates, the 3,5-bis-SF 5 -iodobenzene unit may be an attractive fragment of rational drug design capable of halogen bonding with biomolecules.
\end{abstract}

Keywords: halogen bonding; fluorine; iodine; pentafluorosulfanyl; titration; ab initio calculation; NMR study; drug design

\section{Introduction}

Halogen bonding has attracted considerable attention in recent decades [1-4], particularly after the pioneering work on halogen bonding in supramolecular chemistry by Resnati et al. [5]. The application of halogen bonding has expanded to a wide variety of fields including crystal engineering, supramolecular assemblies, liquid crystals, rational drug design, and organic reactions [1-5]. Halogen bonding is a noncovalent attraction between an electron-deficient region of a halogen atom ( $\sigma$-hole, a halogen bond donor) and an electron-rich center of molecules such as nitrogen, oxygen, and sulfur (Lewis base, a halogen bond acceptor). The strength of the halogen bond increases with an increase of the positive electrostatic potential of the $\sigma$-hole, which can be activated by substitution of an electron-withdrawing group in the neighborhood of the halogen atom. Thus, perfluoroalkyl iodides and perfluoro-iodobenzenes are 
well-studied halogen bond donors. In particular, aromatic iodides are of great interest due to the design of halogen bond donors activated by substitution with several electron-withdrawing substituents [6,7]; pentafluoro-iodobenzene [8,9] and 3,5-bis-nitro( $\left.\mathrm{NO}_{2}\right)$-iodobenzene [10] are representative examples (Figure 1a). Besides, in these planar halogen bond donors, the intermolecular $\pi-\pi$ charge-transfer [11], anion $-\pi[12,13]$, cation $-\pi[14,15]$, and lone pair $-\pi[16-19]$ interactions are always competition for and/or form a combination with halogen bonding in molecular assemblies. These aspects make the design of halogen bond donors more elaborate, especially for applications in the rational design of drugs [20]. Statistical analysis of the protein structure database (PDB) showed that a noncovalent interaction between halogenated ligands (halogen-containing drugs, halogen bond donors) and proteins (halogen bond acceptors) frequently contributes to increasing selectivity and binding affinity [21,22]. This survey revealed that a potential rational drug design is possible when the focus is on halogen bonding interactions of halogenated drug candidates and nitrogen, oxygen, sulfur, and phosphate groups on biomolecules such as peptides, protein, and DNA [1,23].

a)

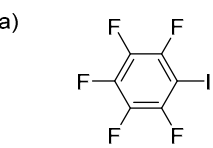

b)
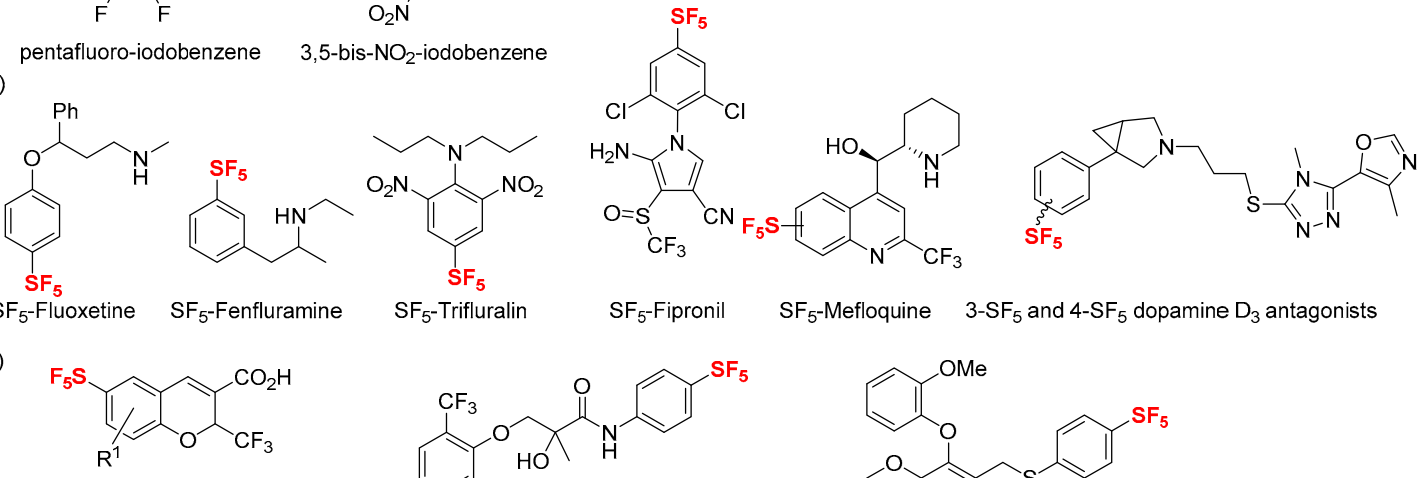

cyclooxygenase. 2 inhibitor $\mathrm{IC}_{50}=0.008-0.34 \mu \mathrm{M}$ (Human COX-2 Enzymes)

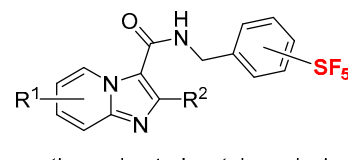

anti mycobacterium tuberculosis $\mathrm{MIC}_{\text {MABA }}=7-310 \mathrm{nM}$ (the microplate alamar blue assay)

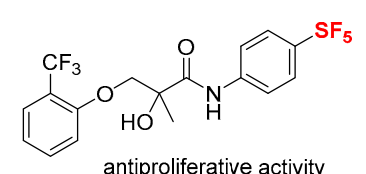

antiproliferative activity $\mathrm{IC}_{50}(\mathrm{tNCaP})=1.17 \mu \mathrm{M}$

$\mathrm{SF}_{5}$-Mefloquine $\quad 3-\mathrm{SF}_{5}$ and $4-\mathrm{SF}_{5}$ dopamine $\mathrm{D}_{3}$ antagonists

d)
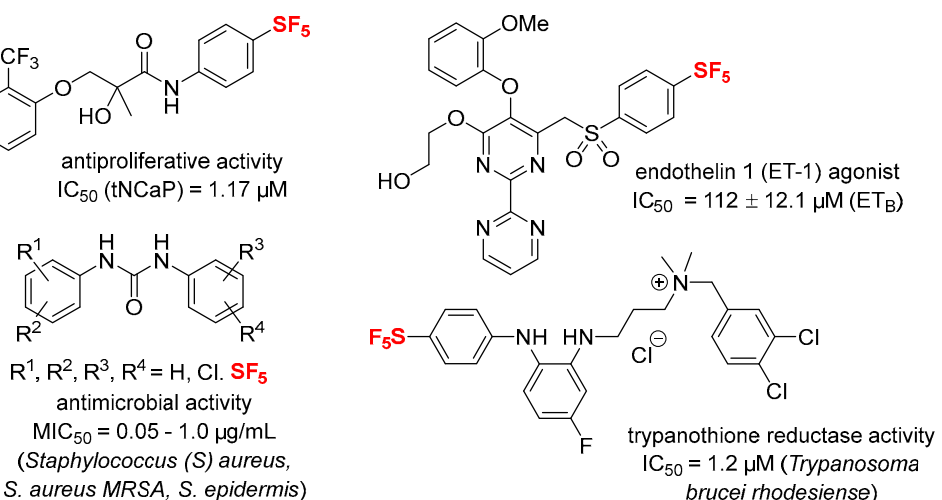
brucei rhodesiense)

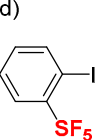

$1 \mathrm{a}$

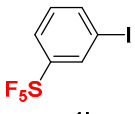

1b

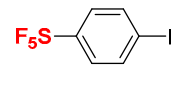

$1 \mathrm{c}$

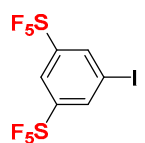

$1 d$

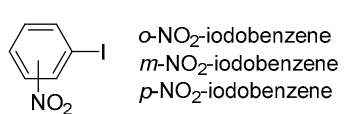

p-NO2-iodobenzene

Figure 1. (a) The standard halogen bond donors pentafluoro-iodobenzene and 3,5-bis- $\mathrm{NO}_{2}$-iodobenzene. (b) Examples of pentafluoro- $\lambda^{6}$-sulfanyl $\left(\mathrm{SF}_{5}\right)$-containing analogs of marketed drugs. (c) Examples of $\mathrm{SF}_{5}$-containing biologically active molecules. (d) Potential halogen bond donors of aryl iodide containing $\mathrm{SF}_{5}$-group(s) and $\mathrm{NO}_{2}$-iodobenzenes (this work).

In this context, we became interested in pentafluoro- $\lambda^{6}$-sulfanyl $\left(\mathrm{SF}_{5}\right)$-substituted iodobenzenes (1) as a new group of halogen bond donors. The $\mathrm{SF}_{5}$ group has attracted much attention in the field of pharmaceuticals and agrochemicals [24-29]. Given the impressive physiochemical properties of the $\mathrm{SF}_{5}$ unit, which include its high electronegativity $\left(\sigma_{m}=0.61, \sigma_{p}=0.68\right.$; nearly equivalent to the $\mathrm{NO}_{2}$ group: $\left.\sigma_{m}=0.73, \sigma_{p}=0.78\right)$ [30-32], high lipophilicity $\left(\pi=1.51\right.$; greater than that of the $\mathrm{CF}_{3}$ group: $\pi=0.88$ and the $\mathrm{NO}_{2}$ group: $\pi=-0.28$ ) [32-34], and steric hindrance (nearly equivalent to that of the tert-butyl group) [34,35], the $\mathrm{SF}_{5}$-containing analogs of marketed drugs are attractive 
candidates in the future drug market (Figure 1b) [36-41]. More and more examples of biologically active $\mathrm{SF}_{5}$-containing drug candidates have been reported in recent years (Figure 1c) [35,38-44]. Extending our research to the design and synthesis of $\mathrm{SF}_{5}$-containing biologically attractive molecules [45-57] and a halogen bonding research program [58,59], we are interested in aryl iodides 1a-d consisting of $\mathrm{SF}_{5}$-group(s) in the benzene ring as potential drug fragments capable of halogen bonding, in particular, 3,5-bis-SF 5 -iodobenzene (1d, Figure $1 \mathrm{~d}$ ). In this research, we have examined the halogen bonding induced by $\mathrm{SF}_{5}$-aryl iodides $\mathbf{1 a}$-d. The $\mathrm{NO}_{2}$-substituted iodobenzenes pentafluoro-iodobenzene and iodobenzene were also examined for comparisons.

\section{Results and Discussion}

The preparation of $o-, m-, p$-SF 5 -iodobenzenes $(\mathbf{1 a - c})$, and 3,5-bis- $\mathrm{SF}_{5}$-iodobenzene (1d) was achieved by the copper-catalyzed halogen exchange reaction of corresponding aryl-bromides according to our previous report $[48,60]$. We first simulated the electrostatic potential values for the iodine atoms of the targeted $\mathrm{SF}_{5}$-iodobenzenes, along with the corresponding values for $\mathrm{NO}_{2}$-iodobenzenes, pentafluoro-iodobenzene, and iodobenzene for comparisons. Molecular electrostatic potential surfaces of iodobenzenes were calculated with the density functional Becke, 3-parameter, Lee-Yang-Parr (B3LYP) level of theory with a $6-311++\mathrm{G}^{* *}$ basis set in a vacuum and water according to the reported method [61] (Figure 2). The numbers indicate the molecular electrostatic potential (MEP, kJ/mol) between the positive point probe and the surface of the molecule at that particular point, and Mulliken charges at the iodine atom. The MEP value indicates a positive surface potential. The results disclose that $1 \mathbf{d}$ shows a more positive electrostatic potential value and Mulliken charge (Figure 2d), almost as same as that of the well-known halogen bond donors 3,5-bis- $\mathrm{NO}_{2}$-iodobenzene (Figure $2 \mathrm{~h}$ ) [10] and pentafluoro-iodobenzene (Figure 2i), independent of calculation in a vacuum and water. It should be noted that $m$ - and $p$-substituted $\mathrm{SF}_{5}$-iodobenzenes $(\mathbf{1 b}, \mathbf{1} \mathbf{c}$, respectively) had a lower Mulliken charge of the iodine atom compared to $o-\mathrm{SF}_{5}$-iodobenzene (1a), indicating a poor ability for halogen bonding (Figure 2a vs. Figure 2b,c). The similar tendency of lower Mulliken charge was also observed for $m$ - and $p$-substituted $\mathrm{NO}_{2}$-iodobenzenes, while $o$-substituted $\mathrm{NO}_{2}$-iodobenzene has a more positive Mulliken charge (Figure 2e vs. Figure 2f,g). Iodobenzene had the most negative value and was thus most de-activated (Figure 2j).

a)

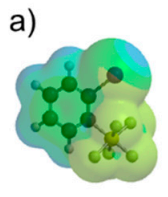

f)

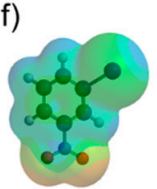

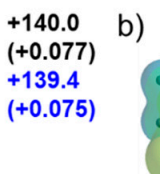

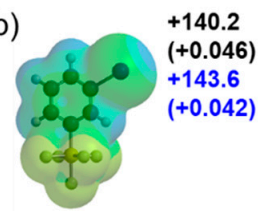

$+137.3$

$(+0.043)$

$+135.9$

$(+0.034)$
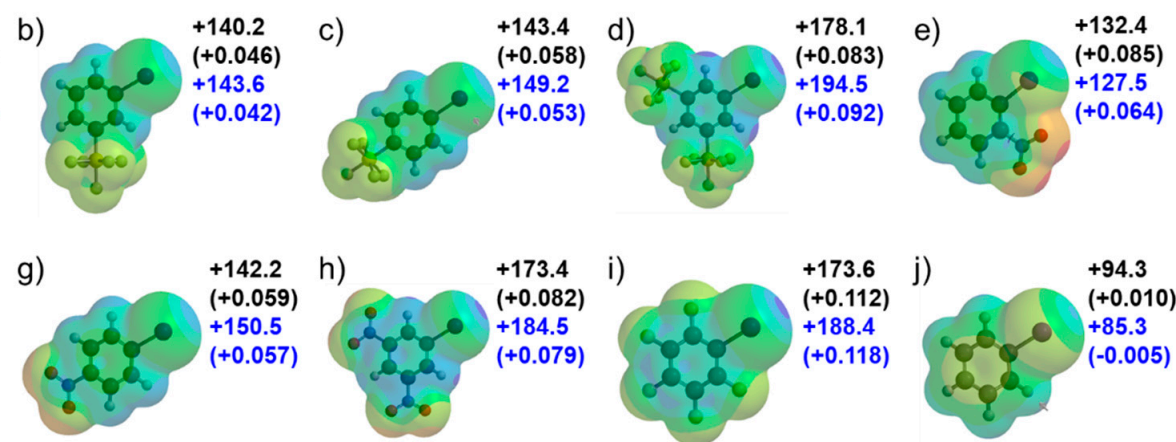

$+142.2 \mathrm{~h})$
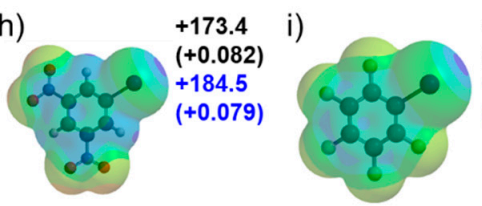

$+173.6 \quad j)$

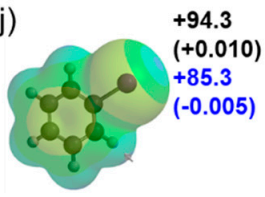

Figure 2. The electrostatic potential surface of molecules with maximum values at iodine atoms in a vacuum (black) and in water (blue). The numbers indicated interaction energy (in kJ/mol) and Mulliken charge in parenthesis; (a) $o-\mathrm{SF}_{5}$-iodobenzene (1a), (b) $m$-SF 5 -iodobenzene (1b), (c) $p$-SF 5 -iodobenzene (1c), (d) ,5-bis-SF 5 -iodobenzene (1d), (e) $o$ - $\mathrm{NO}_{2}$-iodobenzene, (f) $m$ - $\mathrm{NO}_{2}$-iodobenzene, (g) $p$ - $\mathrm{NO}_{2}$ iodobenzene, (h) 3,5-bis- $\mathrm{NO}_{2}$-iodobenzene, (i) pentafluoro-iodobenzene, and (j) iodobenzene.

Next, the intermolecular interactions of iodobenzenes and pyridine were investigated by ab initio molecular orbital calculations. The intermolecular interaction energies $[12,62,63]$ for the $o_{-}, m_{-}$,

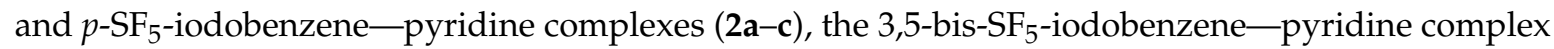
(2d), the 3,5-bis- $\mathrm{NO}_{2}$-iodobenzene-pyridine complex (3), and the pentafluoro-iodobenzene-pyridine complex (4) were calculated by changing the intermolecular separation in a vacuum using the 
second order Møller-Plesset perturbation method and the cc-pVTZ basis set (MP2/cc-pVTZ). The interaction energy potentials calculated for the complexes were compared with the interaction energy potential calculated for the iodobenzene-pyridine complex (5) (Figure 3a). The depths of interaction energy potentials of the $\mathrm{SF}_{5}$-iodobenzene-pyridine complex (2a-d) are deeper than those of the iodobenzene-pyridine complex (5). We note that the potential for $o-\mathrm{SF}_{5}$-substituted $2 \mathrm{a}$ is much deeper than for $m-\mathrm{SF}_{5}-\mathbf{2} \mathbf{b}$ and $p-\mathrm{SF}_{5}-\mathbf{2} \mathbf{c}$, while the potential for 3,5-bis-SF $5-2 \mathbf{d}$ is much deeper. The depths of interaction energy potentials of 3,5-bis-SF $-2 \mathrm{~d}$ and 3,5-bis- $\mathrm{NO}_{2}-3$ are almost the same, and that of the pentafluoro-iodobenzene-pyridine complex (4) is the deepest. The interaction energies by the coupled-cluster calculations with single and double substitutions with non-iterative triple

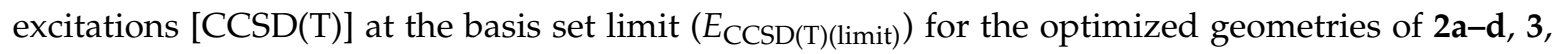
4, and 5 were calculated. [64] The $E_{\mathrm{CCSD}(\mathrm{T})(\mathrm{limit})}$ and the contribution of each intermolecular force are summarized in Table 1 . The calculations show that the electrostatic $\left(E_{\mathrm{es}}\right)$ and dispersion $\left(E_{\mathrm{corr}}\right)$ interactions are the primary sources of the attraction, and the substituent dependence of the electrostatic interactions is mainly responsible for the substituent effects on the magnitude of the attraction of the halogen bonds. These calculated results strongly indicate that substitution of the $\mathrm{SF}_{5}$ group induces halogen bonding, whose strength depends on the position of the substitution and numbers. The interaction energy potentials were also calculated by the density functional theory (DFT) method (B3LYP functionals with Grimme's D3 dispersion correction [65]) with and without polarizable continuum model (PCM) [66] to evaluate the effects of water as shown in Figure 3b,c. The depth of the potential calculated for each complex in water is $20-30 \%$ smaller than that calculated in a vacuum. As expected, 3,5-bis-SF-iodobenzene (1d) is the most efficient template to induce halogen bonding in $\mathrm{SF}_{5}$-iodobenzenes (1), equivalent to the well-known halogen bond donor 3,5-bis- $\mathrm{NO}_{2}$-iodobenzene. The 3,5-bis-substitution is also attractive for improved biological activity, as evidenced in medicinal research $[45,60]$.

a)

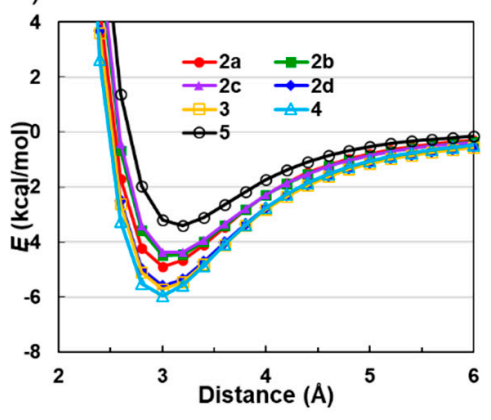

b)

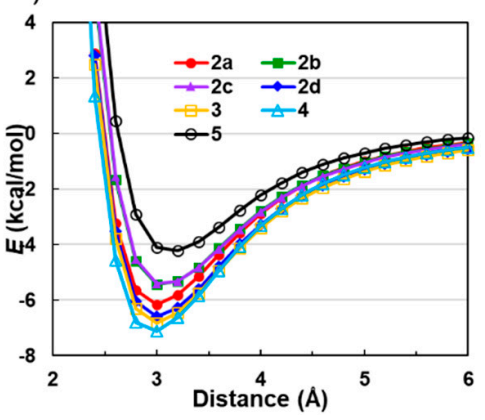

c)

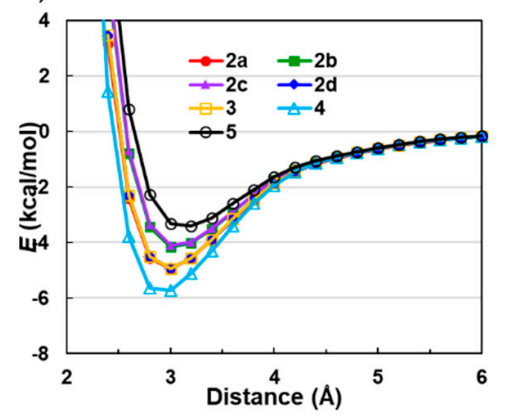

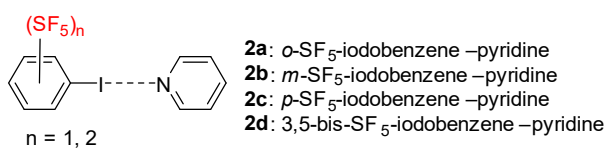
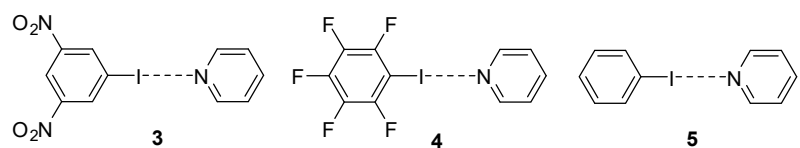

Figure 3. Interaction energy curves (energies versus $\mathrm{I}-\mathrm{N}$ distance $(R)$ ) calculated for the iodobenzene-pyridine complexes (2-5). (a) second order Møller-Plesset perturbation calculations (MP2; vacuum), (b) Becke, 3-parameter, Lee-Yang-Parr calculation with Grimme's D3 dispersion correction (B3LYP-D3, vacuum), and (c) B3LYP-D3 (water). 
Table 1. Electrostatic, induction, and dispersion energies of halogen-bonded complexes a .

\begin{tabular}{|c|c|c|c|c|c|}
\hline \multirow{2}{*}{ Complex } & \multicolumn{5}{|c|}{$E\left(\mathrm{kcal} \mathrm{mol}^{-1}\right)$} \\
\hline & $E_{\text {int }}{ }^{a}$ & $E_{\mathrm{es}} \mathrm{b}$ & $E_{\text {ind }} \mathrm{c}$ & $E_{\text {short }} \mathrm{d}$ & $E_{\text {corr }}{ }^{\mathrm{e}}$ \\
\hline$o-\mathrm{SF}_{5}$-iodobenzene-pyridine $(\mathbf{2 a})$ & -4.88 & -4.48 & -1.32 & 4.43 & -3.52 \\
\hline$m$-SF ${ }_{5}$-iodobenzene-pyridine $(\mathbf{2 b})$ & -4.27 & -4.20 & -1.20 & 4.40 & -3.27 \\
\hline$p$-SF ${ }_{5}$-iodobenzene-pyridine $(2 \mathrm{c})$ & -4.28 & -4.02 & -1.15 & 4.02 & -3.13 \\
\hline 3,5-bis-SF 5 -iodobenzene-pyridine $(\mathbf{2 d})$ & -5.21 & -5.60 & -1.65 & 5.54 & -3.49 \\
\hline 3,5-bis- $\mathrm{NO}_{2}$-iodobenzene-pyridine (3) & -4.83 & -5.23 & -1.52 & 4.46 & -2.53 \\
\hline pentafluoro-iodobenzene-pyridine (4) & -5.71 & -5.83 & -1.68 & 5.11 & -3.31 \\
\hline iodobenzene-pyridine (5) & -3.25 & -2.73 & -0.82 & 3.30 & -2.99 \\
\hline
\end{tabular}

${ }^{a}$ Estimated interaction energy by coupled-cluster calculations with single and double substitutions with non-iterative triple excitations $(\operatorname{CCSD}(\mathrm{T}))$ at the basis set limit $\left(E_{\mathrm{CCSD}(\mathrm{T})(\mathrm{limit})}\right)$. ${ }^{\mathrm{b}}$ Electrostatic energy. ${ }^{\mathrm{c}}$ Induction energy. $\mathrm{d}$ Contribution of short-range (orbital-orbital) interactions $\left(=E_{\mathrm{HF}}-E_{\mathrm{es}}-E_{\mathrm{ind}}\right)$. The interaction energy by Hartree-Fock calculations with aug-cc-pVTZ basis set (HF/aug-cc-pVTZ) was used as $E_{\mathrm{HF}}$. $E_{\text {short }}$ is mainly the contribution of exchange-repulsion interactions. ${ }^{\mathrm{e}}$ Contribution of electron correlation $\left(=E_{\mathrm{int}}-E_{\mathrm{HF}}\right)$. $E_{\mathrm{corr}}$ is mainly dispersion energy.

Encouraged by the results of these calculations, ${ }^{13} \mathrm{C}-\mathrm{NMR}$ titration experiments of $\mathrm{SF}_{5}$-iodobenzenes in the presence of pyridine or tetra(n-butyl)ammonium chloride (TBAC) in $\mathrm{CDCl}_{3}$ to detect the existence of halogen bonding were carried out with comparisons using pentafluoro-iodobenzene and iodobenzene. ${ }^{13} \mathrm{C}-\mathrm{NMR}$ is a well-studied technique to probe halogen bonding [67-70]. Namely, the increase of chemical shifts of the carbon atom bonded to iodine in Ar-I indicates stronger halogen bonding due to lengthening of the carbon-iodine bond by the donation of electrons from the halogen bond acceptor into iodine orbitals [12,71]. Our ${ }^{13} \mathrm{C}-\mathrm{NMR}$ experiments are shown in Figures 4 and 5. First, the chemical shift of the carbon atom bonded to iodine in pentafluoro-iodobenzene increased with an increase in the addition of pyridine or TBAC. This phenomenon confirms the formation of halogen bonding interaction on the $\sigma$-hole of the iodine atom with a Lewis base (nitrogen atom of pyridine, or $\mathrm{Cl}$ anion). The observed up-field shift is a consequence of the donation of electron density from the halogen bond acceptor to the iodine group, and the more significant shifts donated by TBAC with respect to pyridine are consistent with the fact that anions function as better electron donors than pyridines, and form a stronger halogen bond than the nitrogen atom which possesses a neutral lone-pair.

On the other hand, the addition of pyridine or TBAC to iodobenzene leads to a decrease of the chemical shift of the carbon atom bonded to the iodine atom. This observation could be explained by the competitive interaction of the intermolecular $\pi-\pi$ interaction [72] (with pyridine) or the cation- $\pi$ interaction [73] (with tetra ( $n$-butyl) ammonium cation), although this explanation needs further experimental support. Nevertheless, pentafluoro-iodobenzene is an activated halogen bond donor, but iodobenzene is not.

We next examined the titration experiments of a series of $\mathrm{SF}_{5}$-substituted iodobenzenes $(\mathbf{1} \mathbf{a}-\mathbf{d})$ (Figures $4 \mathrm{a}$ and $5 \mathrm{a}$ ). As mentioned above, the changes in chemical shift of pyridine titration are much smaller than those of TBAC titration, while the occurrence of halogen bonding is fundamentally the same. The chemical shifts of the carbon atom bonded to iodine in $o-\mathrm{SF}_{5}$-iodobenzene (1a) and 3,5-bis-SF 5 -iodobenzene (1d) increased after the addition of TBAC, which confirms the occurrence of halogen bonding. On the other hand, opposite phenomena were observed in the case of $m$ - and $p$-SF $F_{5}$-iodobenzene $(\mathbf{1 b}, \mathbf{1} \mathbf{c}$, respectively) with TBAC, which confirms the absence of halogen bonding. These results of the occurrence/absence of halogen bonding depend on the $o^{-}, m_{-}$, or $p$-position of $\mathrm{SF}_{5}$-substitution, and are in good agreement with the Mulliken charges, as shown in Figure 2. This ortho-effect was also observed for the titration experiments of a series of $\mathrm{NO}_{2}$-substituted iodobenzenes (Figures $4 \mathrm{~b}$ and $5 \mathrm{~b}$ ), which are in good agreement with the calculated Mulliken charges, as shown in Figure 2. 

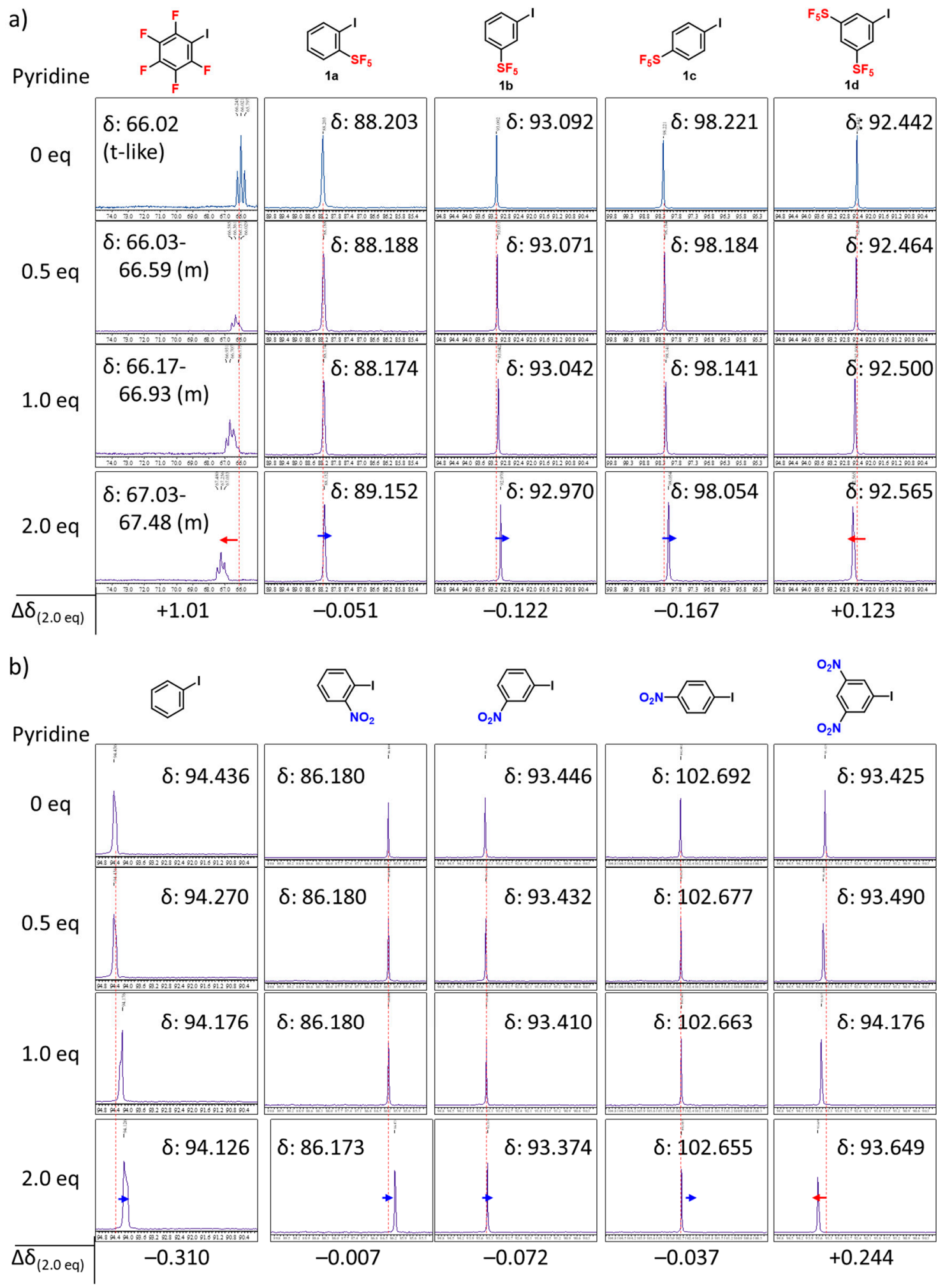

Figure 4. Change in the ${ }^{13} \mathrm{C}-\mathrm{NMR}$ chemical shift of the carbon atom bonded to iodine in $\mathrm{Ar}-\mathrm{I}$ with equivalents of pyridine in $\mathrm{CDCl}_{3}$. (a) pentafluoro-iodobenzene; $o-\mathrm{SF}_{5}$-iodobenzene (1a);

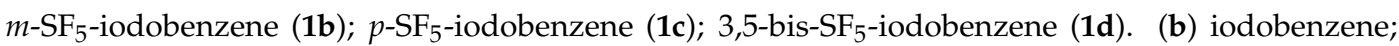
$o$ - $\mathrm{NO}_{2}$-iodobenzene; $m$ - $\mathrm{NO}_{2}$-iodobenzene; $p$ - $\mathrm{NO}_{2}$-iodobenzene; 3,5-bis- $\mathrm{NO}_{2}$-iodobenzene. 

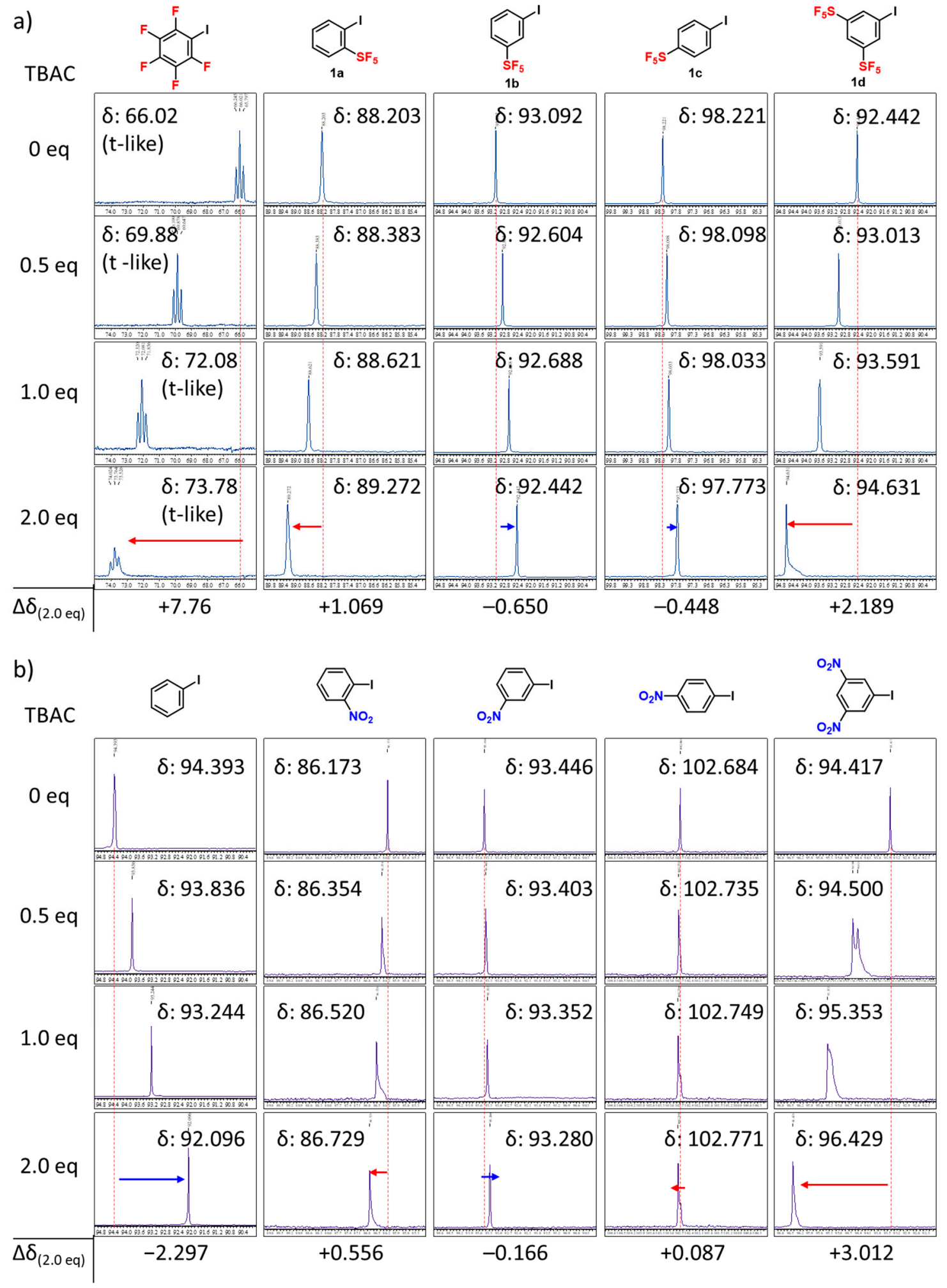

Figure 5. Change in the ${ }^{13} \mathrm{C}-\mathrm{NMR}$ chemical shift of the carbon atom bonded to iodine in Ar-I with equivalents of tetra ( $n$-butyl) ammonium chloride (TBAC) in $\mathrm{CDCl}_{3}$. (a) pentafluoro-iodobenzene; $o$-SF5-iodobenzene (1a); $m$-SF5-iodobenzene (1b); $p$-SF5-iodobenzene (1c); 3,5-bis-SF 5 -iodobenzene (1d). (b) iodobenzene; $o-\mathrm{NO}_{2}$-iodobenzene; $m$ - $\mathrm{NO}_{2}$-iodobenzene; $p$ - $\mathrm{NO}_{2}$-iodobenzene; 3,5-bis- $\mathrm{NO}_{2}$-iodobenzene. 
Finally, we examined the formation of halogen bonding interaction between 3,5-bis-SF 5 iodobenzene (1d) and 1,4-diazabicyclo[2.2.2]octane (DABCO). Since DABCO is a bifunctional halogen bond donor, the 2:1 halogen bonding complex of $1 \mathbf{d}$ and $\mathrm{DABCO}$ is expected. Indeed, X-ray crystallographic analysis of 3,5-bis- $\mathrm{NO}_{2}$-iodobenzene with $\mathrm{DABCO}$ revealed the formation of a 2:1 halogen bonding complex [10]. We thus examined the titration of $\mathbf{1 d}$ by the addition of DABCO (Figure 6). With an increasing amount of DABCO, the chemical shift of carbon attached to iodine increased, providing proof of the formation of halogen bonding of I-N. More interestingly, one singlet peak at $92.442 \mathrm{ppm}$ gradually changed to double singlets at 93.454 and $93.352 \mathrm{ppm}$, which provides evidence of two halogen bonds in the complex from 6 to 7 . This phenomenon suggests that the 2:1-complex 7 is not entirely symmetrical, as in the case of 3,5-bis- $\mathrm{NO}_{2}$-iodobenzene [10].

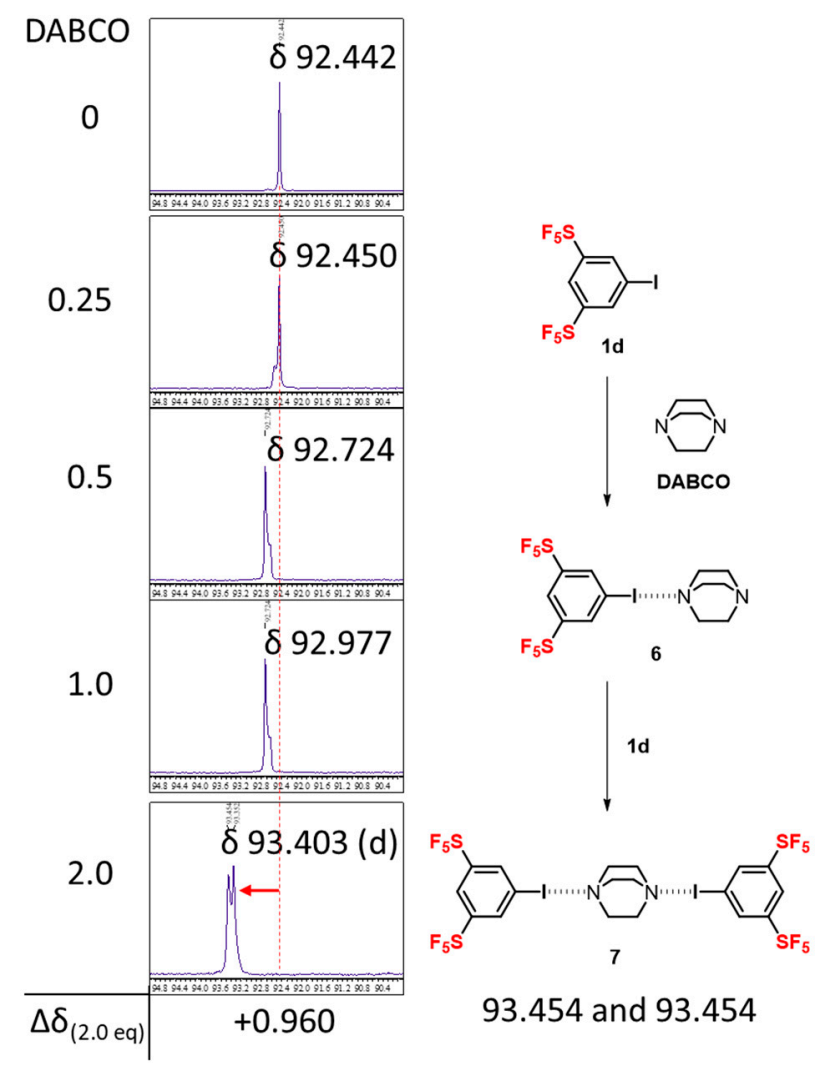

Figure 6. Change in the ${ }^{13} \mathrm{C}-\mathrm{NMR}$ chemical shift of the carbon atom bonded to iodine in $\mathbf{1 d}$ with equivalents of 1,4-diazabicyclo[2.2.2] octane (DABCO) in $\mathrm{CDCl}_{3}$.

\section{Materials and Methods}

All reactions were performed in oven-dried glassware under a positive pressure of nitrogen. Solvents were transferred via syringe and were introduced into the reaction vessels through a rubber septum. Chemicals were purchased and used without further purification unless otherwise noted. All of the reactions were monitored by thin-layer chromatography (TLC) carried out on a $0.25 \mathrm{~mm}$ Merck silica gel $\left(60-\mathrm{F}_{254}\right)($ Kenilworth, NJ, USA). TLC plates were visualized with UV light and 7\% phosphomolybdic acid or $\mathrm{KMnO}_{4}$ in water/heat. Column chromatography was carried out on a column packed with silica gel (60N spherical neutral size 50-60 $\mu \mathrm{m})$ supplied by Kanto Chemical Co., Inc. (Tokyo, Japan). The ${ }^{1} \mathrm{H}-\mathrm{NMR}(300 \mathrm{MHz}),{ }^{19} \mathrm{~F}-\mathrm{NMR}(282 \mathrm{MHz})$, and ${ }^{13} \mathrm{C}-\mathrm{NMR}(126 \mathrm{MHz})$ spectra for each solution in $\mathrm{CDCl}_{3}$ were recorded on Varian Mercury 300 (Agilent Technologies, Palo Alto, CA, USA) and Avance 500 (Bruker, Billerica, MA, USA) NMR spectrometers. Chemical shifts $(\delta)$ are expressed in ppm downfield from internal tetramethylsilane $(\delta=0.0 \mathrm{ppm})$ for ${ }^{1} \mathrm{H}-\mathrm{NMR}, \mathrm{C}_{6} \mathrm{~F}_{6}$ $(\delta=-162.2 \mathrm{ppm})$ for ${ }^{19} \mathrm{~F}-\mathrm{NMR}$, and $\mathrm{CDCl}_{3}(\delta=77.00 \mathrm{ppm})$ for ${ }^{13} \mathrm{C}-\mathrm{NMR}$. Mass spectrometry was 
recorded on a SHIMADZU LCMS-2020 (ESI-MS) (Shimadzu Corporation, Kyoto, Japan). The ${ }^{1} \mathrm{H},{ }^{13} \mathrm{C}$ and ${ }^{19} \mathrm{~F}-\mathrm{NMR}$ spectra of compounds 1 are available in the Supplementary Material.

\subsection{General Procedure of Pentafluoro- $\lambda^{6}$-Sulfanyl Iodobenzene}

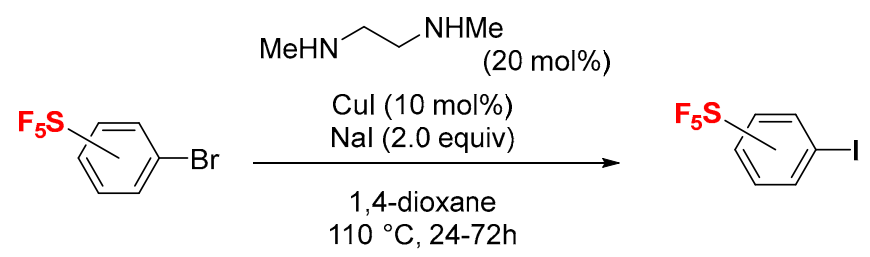

$o-, m-, p$-SF 5 -iodobenzenes $(\mathbf{1 a}-\mathbf{c})$, and 3,5-bis-SF 5 -iodobenzene $(\mathbf{1 d})$ were prepared from corresponding aryl bromides by a copper-catalyzed halogen exchange reaction. [74]. To a flame-dried Schlenk-tube, $\mathrm{CuI}$ (10 mol \%), NaI (2.0 equiv), and aryl bromide (1.0 equiv) were added and evacuated and backfilled with argon. 1,4-Dioxane $(1.0 \mathrm{~mL} / \mathrm{mmol}$ for $\mathrm{ArBr})$ and $N, N^{\prime}$-dimethylethylenediamine ( $20 \mathrm{~mol} \%$ ) were added; the mixture was stirred at room temperature for $3 \mathrm{~min}$ and then at $110{ }^{\circ} \mathrm{C}$ for 24-72 $\mathrm{h}$. The resulting suspension was cooled to room temperature and filtered through a pad of $\mathrm{SiO}_{2}$. The filtrate was diluted in $\mathrm{NaHCO}_{3}$ aq and extracted with $\mathrm{CH}_{2} \mathrm{Cl}_{2}$ three times. The combined organic layer was washed with brine, dried over $\mathrm{Na}_{2} \mathrm{SO}_{4}$, and concentrated under reduced pressure. The crude product was purified by column chromatography on silica gel ( $n$-hexane) to give the desired product.

\subsubsection{Pentafluoro(2-iodophenyl)- $\lambda^{6}$-sulfane (1a)}

92\% yield. ${ }^{1} \mathrm{H}-\mathrm{NMR}\left(300 \mathrm{MHz}, \mathrm{CDCl}_{3}\right) \delta 8.14(\mathrm{~d}, J=7.6 \mathrm{~Hz}, 1 \mathrm{H}), 7.81(\mathrm{~d}, J=8.5 \mathrm{~Hz}, 1 \mathrm{H}), 7.45(\mathrm{t}-\mathrm{like}$, $J=7.5 \mathrm{~Hz}, 1 \mathrm{H}), 7.12$ (t-like, $J=7.4 \mathrm{~Hz}, 1 \mathrm{H}) .{ }^{19} \mathrm{~F}-\mathrm{NMR}\left(282 \mathrm{MHz}, \mathrm{CDCl}_{3}\right) \delta: 83.5$ (quintet, $J=152.6 \mathrm{~Hz}$, $1 \mathrm{~F}), 63.5(\mathrm{~d}, J=151.7 \mathrm{~Hz}, 4 \mathrm{~F}) \mathrm{ppm} .{ }^{13} \mathrm{C}-\mathrm{NMR}\left(126 \mathrm{MHz}, \mathrm{CDCl}_{3}\right) \delta 158.4$ (quintet, $\left.J=16.3 \mathrm{~Hz}\right), 143.9$, 132.2, 130.1 (t-like, $J=5.4 \mathrm{~Hz}), 127.9,88.2 \mathrm{ppm}$. MS (ESI) $\mathrm{m} / z: 353\left[(\mathrm{M}+\mathrm{Na})^{+}\right]$. The product was consistent with previously reported characterization data [60].

\subsubsection{Pentafluoro(3-iodophenyl)- $\lambda^{6}$-sulfane (1b)}

91\% yield. ${ }^{1} \mathrm{H}-\mathrm{NMR}\left(300 \mathrm{MHz}, \mathrm{CDCl}_{3}\right) \delta 8.08(\mathrm{~s}, 1 \mathrm{H}), 7.86(\mathrm{~d}, J=7.6 \mathrm{~Hz}, 1 \mathrm{H}), 7.74(\mathrm{~d}, J=7.4 \mathrm{~Hz}, 1 \mathrm{H})$, $7.22(\mathrm{t}-$ like, $J=8.4 \mathrm{~Hz}, 1 \mathrm{H})$ ppm. ${ }^{19} \mathrm{~F}-\mathrm{NMR}\left(282 \mathrm{MHz}, \mathrm{CDCl}_{3}\right) \delta 82.5$ (quintet, $\left.J=150.9 \mathrm{~Hz}, 1 \mathrm{~F}\right), 62.3(\mathrm{~d}$, $J=151.7 \mathrm{~Hz}, 4 \mathrm{~F}) \mathrm{ppm} .{ }^{13} \mathrm{C}-\mathrm{NMR}\left(126 \mathrm{MHz}, \mathrm{CDCl}_{3}\right) \delta 154.4$ (quintet, $\left.J=17.7 \mathrm{~Hz}\right), 140.6,134.7$ (t-like, $J=4.5 \mathrm{~Hz}), 130.3,125.2,93.1 \mathrm{ppm}$. MS (ESI) $\mathrm{m} / z: 353\left[(\mathrm{M}+\mathrm{Na})^{+}\right]$. The product was consistent with previously reported characterization data [48,75-77].

\subsubsection{Pentafluoro(4-iodophenyl)- $\lambda^{6}$-sulfane (1c)}

91\% yield. ${ }^{1} \mathrm{H}-\mathrm{NMR}\left(300 \mathrm{MHz}, \mathrm{CDCl}_{3}\right) \delta 7.82(\mathrm{~d}, J=8.2 \mathrm{~Hz}, 2 \mathrm{H}), 7.48(\mathrm{~d}, J=8.5 \mathrm{~Hz}, 2 \mathrm{H}) \mathrm{ppm} .{ }^{19} \mathrm{~F}-\mathrm{NMR}$ $\left(282 \mathrm{MHz}, \mathrm{CDCl}_{3}\right) \delta 83.0$ (quintet, $\left.J=150.0 \mathrm{~Hz}, 1 \mathrm{~F}\right), 62.3(\mathrm{~d}, J=150.0 \mathrm{~Hz}, 4 \mathrm{~F})$ ppm. ${ }^{13} \mathrm{C}-\mathrm{NMR}(126 \mathrm{MHz}$, $\mathrm{CDCl}_{3}$ ) $\delta 153.5$ (quintet, $J=18.2 \mathrm{~Hz}$ ), 137.9, 127.5 (t-like, $J=4.5 \mathrm{~Hz}$ ), $98.2 \mathrm{ppm}$. MS (ESI) $\mathrm{m} / z: 353$ $\left[(\mathrm{M}+\mathrm{Na})^{+}\right]$. The product was consistent with previously reported characterization data $[48,76,77]$.

\subsection{4. (5-Iodo-1,3-phenylene)bis(pentafluoro- $\lambda^{6}$-sulfane) (1d)}

95\% yield. ${ }^{1} \mathrm{H}-\mathrm{NMR}\left(300 \mathrm{MHz}, \mathrm{CDCl}_{3}\right) \delta 8.23(\mathrm{~s}, 1 \mathrm{H}), 8.12-8.07(\mathrm{~m}, 2 \mathrm{H}) \mathrm{ppm} .{ }^{19} \mathrm{~F}-\mathrm{NMR}(282 \mathrm{MHz}$, $\left.\mathrm{CDCl}_{3}\right) \delta 80.1$ (quintet, $\left.J=151.7 \mathrm{~Hz}, 1 \mathrm{~F}\right), 62.7(\mathrm{~d}, J=151.7 \mathrm{~Hz}, 4 \mathrm{~F}) \mathrm{ppm} .{ }^{13} \mathrm{C}-\mathrm{NMR}\left(126 \mathrm{MHz}, \mathrm{CDCl}_{3}\right)$ $\delta 154.0$ (quintet, $J=20.0 \mathrm{~Hz}), 137.8,123.5(\mathrm{t}, J=4.5 \mathrm{~Hz}), 92.4 \mathrm{ppm}$. MS (ESI) $m / z: 479\left[(\mathrm{M}+\mathrm{Na})^{+}\right]$. The product was consistent with previously reported characterization data [48]. 


\subsection{Computational Method}

\subsubsection{Calculations for Electrostatic Potential Values}

Molecular electrostatic potential surfaces for $\mathrm{SF}_{5}$ or $\mathrm{NO}_{2}$-iodobenzenes were calculated with the density functional B3LYP level of theory with $6-311++\mathrm{G}^{* *}$ basis set in a vacuum or in a water. The same level of theory was used to calculate the electrostatic potentials with the results presented in Figure 2. All calculations were carried out using Spartan'18 software (Wavefunction, Inc., Irvine, CA, USA). All molecules were geometry optimized with the maxima and minima in the electrostatic potential surface (0.002 e/au isosurface) determined using a positive point charge in the vacuum as a probe. The numbers indicate the interaction energy $(\mathrm{kJ} / \mathrm{mol})$ between the positive point probe and the surface of the molecule at that particular point. A positive value for the interaction energy indicates a positive surface potential.

\subsubsection{Calculations for Interaction Energies}

The Gaussian 09 program [78] was used for the ab initio molecular orbital calculations. The basis sets implemented in the program were used. Electron correlation was accounted for by the second-order Møller-Plesset perturbation (MP2) method [79,80], Becke, 3-parameter, Lee-Yang-Parr (B3LYP) [81-83], and by coupled-cluster calculations with single and double substitutions with non-iterative triple excitations (CCSD(T)) [64]. The basis-set superposition error (BSSE) [84] was corrected for all calculations by using the counterpoise method unless otherwise noted [85]. The geometries of the complexes were optimized at the counterpoise-corrected MP2/6-311G* level. The DGDZVP basis set [86] was used for iodide. The MP2 interaction energies of the complexes at the basis set limit ( $\left.E_{\mathrm{MP2} \text { (limit) }}\right)$ were estimated by the method of Helgaker et al. [87] from the calculated MP2 interaction

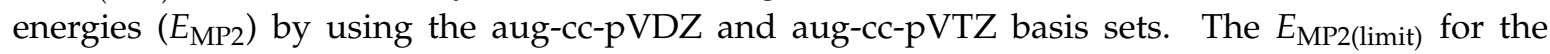
3,5-bis- $\mathrm{NO}_{2}$-iodobenzene-pyridine complex (3) was estimated using the cc-pVDZ and cc-pVTZ basis set. The $\operatorname{CSD}(\mathrm{T})$ interaction energies at the basis set limit $\left(E_{\mathrm{CCSD}(\mathrm{T})(\mathrm{limit})}\right)$ were calculated as the sum of $E_{\mathrm{MP} \text { (limit) }}$ and the estimated CCSD(T) correction term at the basis set limit ( $\triangle \mathrm{CCSD}(\mathrm{T})($ limit)), which was estimated from the difference between the interaction energies calculated at the CCSD(T) and MP2 levels $\left(\triangle \mathrm{CCSD}(\mathrm{T})=E_{\mathrm{CCSD}(\mathrm{T})}-E_{\mathrm{MP} 2}\right)$ by using the $6-31 G^{*}$ basis set $[88,89]$. Electrostatic energies were calculated as the interactions between distributed multipoles [90,91] of interacting molecules by using the ORIENT program [92]. Distributed multipoles up to hexadecapole were obtained on all atoms from the MP2/6-311G ${ }^{* *}$ level wave functions of isolated molecules by using the GDMA program [93]. Induction energies were calculated as the interactions of polarizable sites with the electric field produced by the distributed multipoles of the monomers [94]. The atomic polarizabilities of carbon ( $\alpha=10$ a.u.), nitrogen ( $\alpha=8$ a.u.), oxygen ( $\alpha=6$ a.u.), fluorine ( $\alpha=3$ a.u.), sulfur $(\alpha=20$ a.u.), and iodine ( $\alpha=34$ a.u.) were used for the calculations [95]. The distributed multipoles were used only to estimate the electrostatic and induction energies. The MP2/6-311G ${ }^{* *}$ level optimized geometries of isolated molecules were used to calculate the intermolecular interaction energy potentials. The B3LYP calculations with Grimme's D3 dispersion correction using the cc-pVTZ basis set (B3LYP-D3/cc-pVTZ) level interaction energy potentials [65]) were calculated with and without polarizable continuum model (PCM) [66] to evaluate the effects of the solvent. The B3LYP-D3 level interaction energies were calculated without BSSE correction.

\section{Conclusions}

In conclusion, we have studied the potential of $\mathrm{SF}_{5}$-substituted iodobenzenes as halogen bond donors. The simulated electrostatic potential values of $\mathrm{SF}_{5}$-substituted iodobenzenes, the $\mathrm{ab}$ initio molecular orbital calculations of intermolecular interactions with pyridine, and the ${ }^{13} \mathrm{C}-\mathrm{NMR}$ titration experiments of $\mathrm{SF}_{5}$-substituted iodobenzenes in the presence of halogen bond acceptors were investigated to assess the existence of halogen bonding. It should be noted that halogen bonding of iodobenzenes induced by the $\mathrm{SF}_{5}$-substituted group is strictly dependent on the position of 
$\mathrm{SF}_{5}$-substitution on the benzene ring, i.e., $o-\mathrm{SF}_{5}$-iodobenzene acts as halogen bond donor, while $m$ and $p-\mathrm{SF}_{5}$-iodobenzenes do not. The ortho-effect was also observed for a series of $\mathrm{NO}_{2}$-iodobenzenes. $3,5-\mathrm{Bis}_{-} \mathrm{SF}_{5}$-iodobenzene is the most effective halogen bond donor in the series, and it is almost an equivalent to the well-known 3,5-bis- $\mathrm{NO}_{2}$-iodobenzene, as supported by our calculations and ${ }^{13} \mathrm{C}-\mathrm{NMR}$ titration experiments. These observations are in good agreement with the Mulliken charge of corresponding iodine. Since $\mathrm{SF}_{5}$-containing compounds are promising drug candidates, the present results should provide useful information for the rational design of drugs capable of halogen bonding with biomolecules. The X-ray crystallographic analyses of 3,5-bis-SF 5 -iodobenzene with halogen bond acceptors are now being considered

Supplementary Materials: The following are available online. ${ }^{1} \mathrm{H},{ }^{13} \mathrm{C}$, and ${ }^{19} \mathrm{~F}-\mathrm{NMR}$ spectra of compounds 1 .

Author Contributions: N.S. conceived and designed the experiments and directed the project; K.S. and Y.S. performed the experiments and analyzed the data; S.T. performed the ab initio calculation; Y.S. and N.S. wrote the paper.

Funding: This work was partially supported by the JSPS KAKENHI Grant-in-Aid for Scientific Research (B) Grant Number 18H02553 and the Central Glass Co., Ltd. Award in Synthetic Organic Chemistry, Japan (Y.S.).

Acknowledgments: We thank Ube Industries, Ltd. for the gift of $\mathrm{SF}_{5}$-aryl bromides.

Conflicts of Interest: The authors declare no conflicts of interest.

\section{References}

1. Cavallo, G.; Metrangolo, P.; Milani, R.; Pilati, T.; Priimagi, A.; Resnati, G.; Terraneo, G. The Halogen Bond. Chem. Rev. 2016, 116, 2478-2601. [CrossRef] [PubMed]

2. Bulfield, D.; Huber, S.M. Halogen Bonding in Organic Synthesis and Organocatalysis. Chem. Eur. J. 2016, 22, 14434-14450. [CrossRef] [PubMed]

3. Tepper, R.; Schubert, U.S. Halogen Bonding in Solution: Anion Recognition, Templated Self-Assembly, and Organocatalysis. Angew. Chem. Int. Ed. 2018, 57, 6004-6016. [CrossRef] [PubMed]

4. Wang, H.; Bisoyi, H.K.H.; Urbas, A.M.; Bunning, T.J.; Li, Q. Halogen Bond: An Emerging Supramolecular Tool in the Design of Functional Mesomorphic Materials. Chem. Eur. J. 2019, 25, 1369-1378. [CrossRef] [PubMed]

5. Farina, A.; Meille, S.V.; Messina, M.T.; Metrangolo, P.; Resnati, G.; Vecchio, G. Resolution of Racemic 1,2-Dibromohexafluoropropane through Halogen-Bonded Supramolecular Helices. Angew. Chem. Int. Ed. 1999, 38, 2433-2436. [CrossRef]

6. Politzer, P.; Lane, P.; Concha, M.C.; Ma, Y.; Murray, J.S. An Overview of Halogen Bonding. J. Mol. Model 2007, 13, 305-311. [CrossRef] [PubMed]

7. Politzer, P.; Murraya, J.S.; Clark, T. Halogen Bonding: An Electrostatically-Driven Highly Directional Noncovalent Interaction. Phys. Chem. Chem. Phys. 2010, 12, 7748-7757. [CrossRef]

8. Sarwar, M.G.; Dragisic, B.; Salsberg, L.J.; Gouliaras, C.; Taylor, M.S. Thermodynamics of Halogen Bonding in Solution: Substituent, Structural, and Solvent Effects. J. Am. Chem. Soc. 2010, 132, 1646-1653. [CrossRef]

9. Tsuzuki, S.; Wakisaka, A.; Ono, T.; Sonoda, T. Magnitude and Origin of the Attraction and Directionality of the Halogen Bonds of the Complexes of $\mathrm{C}_{6} \mathrm{~F}_{5} \mathrm{X}$ and $\mathrm{C}_{6} \mathrm{H}_{5} \mathrm{X}(\mathrm{X}=\mathrm{I}, \mathrm{Br}, \mathrm{Cl}$ and $\mathrm{F})$ with Pyridine. Chem. Eur. J. 2012, 18, 951-960. [CrossRef]

10. Raatikainen, K.; Rissanen, K. Hierarchical halogen bonding induces polymorphism. Cryst. Eng. Comm. 2009, 11, 750-752. [CrossRef]

11. Rosokha, S.V.; Loboda, E.A. Interplay of Halogen and $\pi-\pi$ Charge-Transfer Bondings in Intermolecular Associates of Bromo- or Iododinitrobenzene with Tetramethyl-p-phenylenediamine. J. Phys. Chem. A 2015, 119, 3833-3842. [CrossRef] [PubMed]

12. Yan, X.Q.; Zhao, X.R.; Wang, H.; Jin, W.J. The Competition of $\sigma-\mathrm{Hole}^{\prime \cdots} \mathrm{Cl}^{-}$and $\pi-\mathrm{Hole} \cdots \mathrm{Cl}^{-}$Bonds between $\mathrm{C}_{6} \mathrm{~F}_{5} \mathrm{X}(\mathrm{X}=\mathrm{F}, \mathrm{Cl}, \mathrm{Br}, \mathrm{I})$ and the Chloride Anion and Its Potential Application in Separation Science. J. Phys. Chem. B 2014, 118, 1080-1087. [CrossRef] [PubMed] 
13. Viger-Gravel, J.; Leclerc, S.; Korobkov, I.; Bryce, D. Direct Investigation of Halogen Bonds by Solid-State Multinuclear Magnetic Resonance Spectroscopy and Molecular Orbital Analysis. J. Am. Chem. Soc. 2014, 136, 6929-6942. [CrossRef] [PubMed]

14. Ma, J.C.; Dougherty, D.A. The Cation- $\pi$ Interaction. Chem. Rev. 1997, 97, 1303-1324. [CrossRef] [PubMed]

15. Zhan, Y.-Y.; Kojima, T.; Koide, T.; Tachikawa, M.; Hiraoka, S. A Balance between van der Waals and Cation $-\pi$ Interactions Stabilizes Hydrophobic Assemblies. Chem. Eur. J. 2018, 24, 9130-9135. [CrossRef] [PubMed]

16. Kozelka, J. Lone Pair- $\pi$ Interactions in Biological Systems: Occurrence, Function, and Physical Origin. Eur. Biophys. J. 2017, 46, 729-737. [CrossRef] [PubMed]

17. Mooibroek, T.J.; Gamez, P.; Reedijk, J. Lone pair- $\pi$ Interactions: A New Supramolecular bond? Cryst. Eng. Comm. 2008, 10, 1501-1515. [CrossRef]

18. Bauzá, A.; Mooibroek, T.J.; Frontera, A. The Bright Future of Unconventional $\sigma / \pi$-Hole Interactions. ChemPhysChem 2015, 16, 2496-2517. [CrossRef]

19. Savastano, M.; García-Gallarín, C.; de la Torre, M.D.L.; Bazzicalupi, C.; Bianchi, A.; Melguizo, M. Anion- $\pi$ and Lone Pair- $\pi$ Interactions with s-Tetrazine-Based Ligands. Coord. Chem. Rev. 2019, 397, 112-137. [CrossRef]

20. Mendez, L.; Henriquez, G.; Sirimulla, S.; Narayan, M. Looking Back, Looking Forward at Halogen Bonding in Drug Discovery. Molecules 2017, 22, 1397. [CrossRef]

21. Parisini, E.; Metrangolo, P.; Pilati, T.; Resnati, G.; Terraneo, G. Halogen Bonding in Halocarbon-Protein Complexes: A Structural Survey. Chem. Soc. Rev. 2011, 40, 2267-2278. [CrossRef] [PubMed]

22. Scholfield, M.R.; Vander Zanden, V.M.; Carter, M.; Ho, P.S. Halogen Bonding (X-Bonding): A Biological Perspective. Protein Sci. 2013, 22, 139-152. [CrossRef] [PubMed]

23. Kolář, M.H.; Tabarrini, O. Halogen Bonding in Nucleic Acid Complexes. J. Med. Chem. 2017, 60, 8681-8690. [CrossRef]

24. Lentz, D.; Seppelt, K.; Akiba, K.-Y. Chemistry of Hypervalent Compounds; Akiba, K.-Y., Ed.; Wiley-VCH: New York, NY, USA, 1999.

25. Winter, R.W.; Dodean, R.A.; Gard, G.L. Fluorine Containing Synthons; Soloshonok, V.A., Ed.; American Chemical Society: Washington, DC, USA, 2005.

26. Altomonte, S.; Zanda, M. Synthetic Chemistry and Biological Activity of Pentafluorosulphanyl $\left(\mathrm{SF}_{5}\right) \mathrm{Organic}$ Molecules. J. Fluorine Chem. 2012, 143, 57-93. [CrossRef]

27. Kirsch, P.; Röschenthaler, G.-V. Current Fluoroorganic Chemistry, Vol. 949; American Chemical Society: Washington, DC, USA, 2007.

28. Kirsch, P. Modern Fluoroorganic Chemistry; Wiley-VCH Verlag GmbH Co. KGaA: Weinheim, Germany, 2013.

29. Savoie, P.R.; Welch, J.T. Preparation and Utility of Organic Pentafluorosulfanyl-Containing Compounds. Chem. Rev. 2015, 115, 1130-1190. [CrossRef] [PubMed]

30. Kirsch, P. The Petafluorosulfuranyl Group and Related Structures. In Modern Fluoroorganic Chemistry; Wiley-VCH: Weinheim, Germany, 2004; pp. 146-156.

31. Sheppard, W.A. Arylsulfur Pentafluorides. J. Am. Chem. Soc. 1962, 84, 3064-3072. [CrossRef]

32. Hansch, C.; Leo, A.; Unger, S.H.; Kim, K.H.; Nikaitani, D.; Lien, E.J. "Aromatic" Substituent Constants for Structure-Activity Correlations. J. Med. Chem. 1973, 16, 1207-1216. [CrossRef] [PubMed]

33. Hansch, C.; Muir, R.M.; Fujita, T.; Maloney, P.P.; Geiger, F.; Streich, M. The Correlation of Biological Activity of Plant Growth Regulators and Chloromycetin Derivatives with Hammett Constants and Partition Coefficients. J. Am. Chem. Soc. 1963, 85, 2817-2824. [CrossRef]

34. Bégué, J.-P.; Bonnet-Delpon, D. Bioorganic and Medicinal Chemistry of Fluorine; Wiley: Hoboken, Germany, 2008.

35. Westphal, M.V.; Wolfstädter, B.T.; Plancher, J.-M.; Gatfield, J.; Carreira, E.M. Evaluation of tert-Butyl Isosteres: Case Studies of Physicochemical and Pharmacokinetic Properties, Efficacies, and Activities. Chem. Med. Chem. 2015, 10, 461-469. [CrossRef]

36. Savoie, P.R.; von Hahmann, C.N.; Penger, A.; Wei, Z.; Welch, J.T. The Control of Stereochemistry by the Pentafluorosulfanyl Group. Org. Biomol. Chem. 2018, 16, 3151-3159. [CrossRef]

37. Joliton, A.; Plancher, J.-M.; Carreira, E.M. Formation of $\alpha-\mathrm{SF}_{5}$-Enolate Enables Preparation of 3-SF 5 -Quinolin-2-ones, 3-SF5-Quinolines, and 3-SF 5 -Pyridin-2-ones: Evaluation of their Physicochemical Properties. Angew. Chem. Int. Ed. 2016, 55, 2113-2117. [CrossRef] [PubMed] 
38. Kokkonda, S.; Deng, X.; White, K.L.; Coteron, J.M.; Marco, M.; de las Heras, L.; White, J.; Mazouni, F.E.; Tomchick, D.R.; Manjalanagara, K.; et al. Tetrahydro-2-naphthyl and 2-Indanyl Triazolopyrimidines Targeting Plasmodium falciparum Dihydroorotate Dehydrogenase Display Potent and Selective Antimalarial Activity. J. Med. Chem. 2016, 59, 5416-5431. [CrossRef] [PubMed]

39. Zhang, Y.; Wang, Y.; He, C.; Liu, X.; Lu, Y.; Chen, T.; Pan, Q.; Xiong, J.; She, M.; Tu, Z.; et al. PentafluorosulfanylSubstituted Benzopyran Analogues as New Cyclooxygenase-2 Inhibitors with Excellent Pharmacokinetics and Efficacy in Blocking Inflammation. J. Med. Chem. 2017, 60, 4135-4146. [CrossRef] [PubMed]

40. Moraski, G.C.; Bristol, R.; Seeger, N.; Boshoff, H.L.; Tsang, P.S.-Y.; Miller, M.J. Preparation and Evaluation of Potent Pentafluorosulfanyl Substituted Anti-Tuberculosis Compounds. Chem. Med. Chem. 2017, 12, 1108-1115. [CrossRef] [PubMed]

41. Sansook, S.; Ocasio, C.A.; Day, I.J.; Tizzard, G.J.; Coles, S.J.; Fedorov, O.; Bennett, J.M.; Elkins, J.M.; Spencer, J. Synthesis of kinase inhibitors containing a pentafluorosulfanyl moiety. Org. Biomol. Chem. 2017, 15, 8655-8660. [CrossRef] [PubMed]

42. Sowaileh, M.F.; Hazlitt, R.A.; Colby, D.A. Application of the Pentafluorosulfanyl Group as a Bioisosteric Replacement. Chem. Med. Chem. 2017, 12, 1481-1490. [CrossRef] [PubMed]

43. Pujol, E.; Blanco-Cabra, N.; Julián, E.; Leiva, R.; Torrents, E.; Vázquez, S. Pentafluorosulfanyl-Containing Triclocarban Analogs with Potent Antimicrobial Activity. Molecules 2018, 23, 2853. [CrossRef] [PubMed]

44. Pertusati, F.; Ferla, S.; Bassetto, M.; Brancale, A.; Khandil, S.; Westwell, A.D.; McGuigan, C. A New Series of Bicalutamide, Enzalutamide and Enobosarm Derivatives Carrying Pentafluorosulfanyl $\left(\mathrm{SF}_{5}\right)$ and Pentafluoroethyl $\left(\mathrm{C}_{2} \mathrm{~F}_{5}\right)$ Substituents: Improved Antiproliferative Agents against Prostate Cancer. Eur. J. Med. Chem. 2019, 180,1-14. [CrossRef]

45. Yang, Y.-D.; Lu, X.; Tokunaga, E.; Shibata, N. 3,5-Bis(pentafluorosulfanyl)phenylboronic Acid: A New Organocatalyst for Conia-Ene Carbocyclization of 1,3-Dicarbonyl Compounds Having Terminal Alkynes. J. Fluor. Chem. 2012, 143, 204-209. [CrossRef]

46. Yang, Y.-D.; Tokunaga, E.; Akiyama, H.; Saito, N.; Shibata, N. Bis(pentafluorosulfanyl)phenyl Azide as an Expeditious Tool for Click Chemistry toward Antitumor Pharmaceuticals. Chem. Med. Chem. 2014, 9, 913-917. [CrossRef]

47. Iida, N.; Tokunaga, E.; Saito, N.; Shibata, N. Synthesis and Property of Novel Phthalocyanine Having a 3,5-Bis-pentafluorosulfanylphenyl Group on the $\alpha$-Peripheral Position. J. Fluor. Chem. 2014, 168, $93-98$. [CrossRef]

48. Matsuzaki, K.; Okuyama, K.; Tokunaga, E.; Saito, N.; Shiro, M.; Shibata, N. Synthesis of Diaryliodonium Salts Having Pentafluorosulfanylarenes and Their Application to Electrophilic Pentafluorosulfanylarylation of $C_{-}, O_{-}, N_{-}$, and S-Nucleophiles. Org. Lett. 2015, 17, 3038-3041. [CrossRef] [PubMed]

49. Iida, N.; Tanaka, K.; Tokunaga, E.; Mori, S.; Saito, N.; Shibata, N. Synthesis of Phthalocyanines with a Pentafluorosulfanyl Substituent at Peripheral Positions. Chem. Open 2015, 4, 698-702. [CrossRef] [PubMed]

50. Kosobokov, M.; Cui, B.; Balia, A.; Matsuzaki, K.; Tokunaga, E.; Saito, N.; Shibata, N. Importance of a Fluorine Substituent for the Preparation of meta- and para-Pentafluoro- $\lambda^{6}$-sulfanyl-Substituted Pyridines. Angew. Chem. Int. Ed. 2016, 55, 10781-10785. [CrossRef] [PubMed]

51. Das, P.; Takada, M.; Matsuzaki, K.; Saito, N.; Shibata, N. SF 5 -Pyridylaryl- $\lambda^{3}$-iodonium Salts and Their Utility as Electrophilic Reagents to Access $\mathrm{SF}_{5}$-pyridine Derivatives in the Late-Stage of Synthesis. Chem. Commun. 2017, 53, 3850-3853. [CrossRef] [PubMed]

52. Cui, B.; Jia, S.; Tokunaga, E.; Saito, N.; Shibata, N. Silver-Induced Self-Immolative Cl-F Exchange Fluorination of Arylsulfur Chlorotetrafluorides: Synthesis of Arylsulfur Pentafluorides. Chem. Commun. 2017, 53, 12738-12741. [CrossRef] [PubMed]

53. Das, P.; Tokunaga, E.; Shibata, N. Recent Advancements in the Synthesis of Pentafluorosulfanyl $\left(\mathrm{SF}_{5}\right)$-Containing Heteroaromatic Compounds. Tetrahedron Lett. 2017, 58, 4803-4815. [CrossRef]

54. Das, P.; Takada, M.; Tokunaga, E.; Saito, N.; Shibata, N. Synthesis of Pyridine trans-Tetrafluoro- $\lambda^{6}$-sulfane Derivatives via Radical Additions. Org. Chem. Front. 2018, 5, 719-724. [CrossRef]

55. Das, P.; Niina, K.; Hiromura, T.; Tokunaga, E.; Saito, N.; Shibata, N. An Eccentric Rod-Like Linear Connection of Two Heterocycles: Synthesis of Pyridine trans-Tetrafluoro- $\lambda^{6}$-sulfanyl Triazoles. Chem. Sci. 2018, 9, 4931-4936. [CrossRef]

56. Cui, B.; Shibata, N. The Story of $\mathrm{SF}_{5}$-Substituted Pyridines. Phosphorus, Sulfur Silicon Relat. Elem. 2019, 194, 658-663. [CrossRef] 
57. Saidalimu, I.; Liang, Y.; Niina, K.; Tanagawa, K.; Saito, N.; Shibata, N. Synthesis of Aryl and Heteroaryl Tetrafluoro- $\lambda^{6}$-sulfanyl Chlorides from Diaryl Disulfides Using Trichloroisocyanuric Acid and Potassium Fluoride. Org. Chem. Front. 2019, 6, 1157-1161. [CrossRef]

58. Cui, B.; Kosobokov, M.; Matsuzaki, K.; Tokunaga, E.; Shibata, N. IF 5 Affects the Final Stage of the Cl-F Exchange Fluorination in the Synthesis of Pentafluoro- $\lambda^{6}$-sulfanyl-pyridines, Pyrimidines and Benzenes with Electron-Withdrawing Substituents. Chem. Commun. 2017, 53, 5997-6000. [CrossRef] [PubMed]

59. Matsuzaki, K.; Uno, H.; Tokunaga, E.; Shibata, N. Fluorobissulfonylmethyl Iodides: An Efficient Scaffold for Halogen Bonding Catalysts with an sp ${ }^{3}$-Hybridized Carbon-Iodine Moiety. ACS Catal. 2018, 8, 6601-6605. [CrossRef]

60. Das, P.; Tokunaga, E.; Akiyama, H.; Doi, H.; Saito, N.; Shibata, N. Synthesis of Fluoro-Functionalized Diaryl- $\lambda^{3}$-iodonium Salts and Their Cytotoxicity against Human Lymphoma U937 Cells. Beilstein J. Org. Chem. 2018, 14, 364-372. [CrossRef] [PubMed]

61. Aakeröy, C.B.; Wijethunga, T.K.; Desper, J.; Đaković, M. Crystal Engineering with Iodoethynylnitrobenzenes: A Group of Highly Effective Halogen-Bond Donors. Cryst. Growth Des. 2015, 15, 3853-3861. [CrossRef]

62. Tsuzuki, S.; Sato, N. Origin of Attraction in Chalcogen-Nitrogen Interaction of 1,2,5-chalcogenadiazole Dimers. J. Phys. Chem. B 2013, 117, 6849-6855. [CrossRef] [PubMed]

63. Tsuzuki, S.; Uchimaru, T.; Wakisaka, A.; Ono, T. Magnitude and Directionality of Halogen Bond of Benzene with $\mathrm{C}_{6} \mathrm{~F}_{5} \mathrm{X}, \mathrm{C}_{6} \mathrm{H}_{5} \mathrm{X}$, and $\mathrm{CF}_{3} \mathrm{X}(\mathrm{X}=\mathrm{I}, \mathrm{Br}, \mathrm{Cl}$, and F). J. Phys. Chem. A 2016, 120, 7020-7029. [CrossRef] [PubMed]

64. Pople, J.A.; Head-Gordon, M.; Raghavachari, K. Quadratic Configuration Interaction. A General Technique for Determining Electron Correlation Energies. J. Chem. Phys. 1987, 87, 5968-5975. [CrossRef]

65. Grimme, S.; Antony, J.; Ehrlich, S.; Krieg, H. A consistent and accurate ab initio parameterization of density functional dispersion correction (DFT-D) for the 94 elements H-Pu. J. Chem. Phys. 2010, 132, 154104. [CrossRef]

66. Miertuš, S.; Scrocco, E.; Tomasi, J. Electrostatic Interaction of a Solute with a Continuum. A Direct Utilization of ab initio Molecular Potentials for the Prevision of Solvent Effects. Chem. Phys. 1981, 55, 117-129. [CrossRef]

67. He, W.; Ge, Y.-C.; Tan, C.-H. Halogen-Bonding-Induced Hydrogen Transfer to C=N Bond with Hantzsch Ester. Org. Lett. 2014, 16, 3244-3247. [CrossRef] [PubMed]

68. Walter, S.M.; Kniep, F.; Herdtweck, E.; Huber, S.M. Halogen-Bond-Induced Activation of a Carbon-Heteroatom Bond. Angew. Chem. Int. Ed. 2011, 50, 7187-7191. [CrossRef] [PubMed]

69. Saito, M.; Kobayashi, Y.; Tsuzuki, S.; Takemoto, Y. Electrophilic Activation of Iodonium Ylides by Halogen-Bond-Donor Catalysis for Cross-Enolate Coupling. Angew. Chem. Int. Ed. 2017, 56, 7653-7657. [CrossRef] [PubMed]

70. Guha, S.; Sekar, G. Metal-Free Halogen(I) Catalysts for the Oxidation of Aryl(heteroaryl)methanes to Ketones or Esters: Selectivity Control by Halogen Bonding. Chem. Eur. J. 2018, 24, 14171-14182. [CrossRef] [PubMed]

71. Tang, Q.; Li, Q. Non-additivity of F Substituent in Enhancing the Halogen Bond in $\mathrm{C}_{6} \mathrm{H}_{5} \mathrm{I} \cdots \mathrm{NCH}$. Comput. Theor. Chem. 2015, 1070, 21-26. [CrossRef]

72. Ellington, T.L.; Reves, P.L.; Simms, B.L.; Wilson, J.L.; Watkins, D.L.; Tschumper, G.S.; Hammer, N.I. Quantifying the Effects of Halogen Bonding by Haloaromatic Donors on the Acceptor Pyrimidine. ChemPhysChem 2017, 18, 1267-1273. [CrossRef] [PubMed]

73. Estarellas, C.; Frontera, A.; Quiñonero, D.; Deyà, P.M. Radical Cation $\left(\mathrm{C}^{\bullet+}-\pi\right)$ and Radical Anion $\left(\mathrm{A}^{\bullet-}-\pi\right)$ Interactions with Aromatic Rings: Energetic, Orbitalic and Spin Density Considerations. Phys. Chem. Chem. Phys. 2011, 13, 16698-16705. [CrossRef]

74. Klapars, A.; Buchwald, S.L. Copper-Catalyzed Halogen Exchange in Aryl Halides: An Aromatic Finkelstein Reaction. J. Am. Chem. Soc. 2002, 124, 14844-14845. [CrossRef]

75. Joliton, A.; Carreira, E.M. Ir-Catalyzed Preparation of $\mathrm{SF}_{5}-$ Substituted Potassium Aryl Trifluoroborates via C-H Borylation and Their Application in the Suzuki-Miyaura Reaction. Org. Lett. 2013, 15, 5147-5149. [CrossRef]

76. Bowden, R.D.; Comina, P.J.; Greenhall, M.P.; Kariuki, B.M.; Loveday, A.; Philp, D. A New Method for the Synthesis of Aromatic Sulfurpentafluorides and Studies of the Stability of the Sulfurpentafluoride Group in Common Synthetic Transformations. Tetrahedron 2000, 56, 3399-3408. [CrossRef]

77. Iakobson, G.; Du, J.; Slawin, A.M.Z.; Beier, P. Pyridine-promoted Dediazoniation of Aryldiazonium Tetrafluoroborates: Application to the Synthesis of $\mathrm{SF}_{5}$-substituted Phenylboronic Esters and Iodobenzenes. Beilstein J. Org. Chem. 2015, 11, 1494-1502. [CrossRef] [PubMed] 
78. Frisch, M.J.; Trucks, G.W.; Schlegel, H.B.; Scuseria, G.E.; Robb, M.A.; Cheeseman, J.R.; Scalmani, G.; Barone, V.; Mennucci, B.; Petersson, G.A.; et al. Gaussian 09, Revision C.01; Gaussian, Inc.: Wallingford, CT, USA, 2009.

79. Møller, C.; Plesset, M.S. Note on an Approximation Treatment for Many-Electron Systems. Phys. Rev. 1934, 46, 618-622. [CrossRef]

80. Lee, C.; Yang, W.; Parr, R.G. Development of the Colle-Salvetti correlation-energy formula into a functional of the electron density. Phys. Rev. B 1988, 37, 785-789. [CrossRef] [PubMed]

81. Becke, A.D.J. A new mixing of Hartree-Fock and local density-functional theories. Chem. Phys. 1993, 98, 1372-1377. [CrossRef]

82. Becke, A.D.J. Density-functional thermochemistry. III. The role of exact exchange. Chem. Phys. 1993, 98, 5648-5652. [CrossRef]

83. Head-Gordon, M.; Pople, J.A.; Frisch, M.J. MP2 Energy Evaluation by Direct Methods. Chem. Phys. Lett. 1988, 153, 503-506. [CrossRef]

84. Ransil, B.J. Studies in Molecular Structure. IV. Potential Curve for the Interaction of Two Helium Atoms in Single-Configuration LCAO MO SCF Approximation. J. Chem. Phys. 1961, 34, 2109-2118. [CrossRef]

85. Boys, S.F.; Bernardi, F. The Calculation of Small Molecular Interactions by the Differences of Separate Total Energies. Some Procedures with Reduced Errors. Mol. Phys. 1970, 19, 553-566. [CrossRef]

86. Godbout, N.; Salahub, D.R.; Andzelm, J.; Wimmer, E. Optimization of Gaussian-Type Basis Sets for Local Spin Density Functional Calculations. Part I. Boron through Neon, Optimization Technique and Validation. Can. J. Chem. 1992, 70, 560-571. [CrossRef]

87. Helgaker, T.; Klopper, W.; Koch, H.; Noga, J. Basis-Set Convergence of Correlated Calculations on Water. J. Chem. Phys. 1997, 106, 9639-9646. [CrossRef]

88. Tsuzuki, S.; Honda, K.; Uchimaru, T.; Mikami, M.; Tanabe, K. Origin of Attraction and Directionality of the $\pi / \pi$ Interaction: Model Chemistry Calculations of Benzene Dimer Interaction. J. Am. Chem. Soc. 2002, 124, 104-112. [CrossRef] [PubMed]

89. Shibasaki, K.; Fujii, A.; Mikami, M.; Tsuzuki, S. Magnitude and Nature of Interactions in Benzene-X ( $\mathrm{X}=$ Ethylene and Acetylene) in the Gas Phase: Significantly Different $\mathrm{CH} / \pi$ Interaction of Acetylene As Compared with Those of Ethylene and Methane. J. Phys. Chem. A 2007, 111, 753-758. [CrossRef] [PubMed]

90. Stone, A.J.; Alderton, M. Distributed Multipole Analysis. Mol. Phys. 1985, 56, 1047-1064. [CrossRef]

91. Stone, A.J. The Theory of Intermolecular Forces, 2nd ed.; Oxford University Press: Oxford, UK, 2013.

92. Stone, A.J.; Dullweber, A.; Hodges, M.P.; Popelier, P.L.A.; Wales, D.J. Orient: A Program for Studying Interactions between Molecules, v. 3.2; University of Cambridge: Cambridge, UK, 1995.

93. Stone, A.J. Distributed Multipole Analysis: Stability for Large Basis Sets. J. Chem. Theory Comput. 2005, 1, 1128-1132. [CrossRef] [PubMed]

94. Stone, A.J. Distributed Polarizabilities. Mol. Phys. 1985, 56, 1065-1082. [CrossRef]

95. Van Duijnen, P.T.; Swart, M. Molecular and Atomic Polarizabilities: Thole's Model Revisited. J. Phys. Chem. A 1998, 102, 2399-2407. [CrossRef]

Sample Availability: Samples of the compounds 1a-d are available from the authors.

(C) 2019 by the authors. Licensee MDPI, Basel, Switzerland. This article is an open access article distributed under the terms and conditions of the Creative Commons Attribution (CC BY) license (http://creativecommons.org/licenses/by/4.0/). 